Record Office to serve them. The staff will give every assistance in the identification and use of records and will supply details of record holdings on request. To avoid possible delay it is requested that intending visitors should give notice of their arrival and of their subjects of study. Subject to statutory provision, records less than fifty years old are not available to readers. Application should be made to Government Archives and Museum, P.O. Box I 16, Zanzibar.

\title{
The Italian Centre for Cultural Relations with the Swahili Area
}

THE Italian Centre for Cultural Relations with the Swahili Area has been formed in Rome in order to promote friendship and collaboration between the peoples of Kenya, Tanganyika, Uganda, Katanga, and other neighbouring Swahili speakers, and Italy. The Centre aims to promote and publish linguistic, historical, sociological, and economic research about the Swahili-speaking areas and to encourage the study of Swahili language and literature in Italy. It hopes to award prizes and scholarships and to co-operate with other organizations having similar aims. The President of the Centre is Dr. Andrea Oscar Crapanzano and the address, Casella Postale 2437, Roma.

\section{New Library of Congress Bibliography of French Equatorial Africa and French Trust Territories}

A NEw 78-page bibliography recently issued by the Library of Congress-Official Publications of French Equatorial Africa, French Cameroons, and Togo, 1946-58: $A$ Guide-is the ninth in its series of guides to documents of African countries. It has been compiled by Julian W. Witherell of the Library's African Section and lists publications issued during the term of the Fourth Republic by the Governments of French Equatorial Africa and its four component territories (Chad, Gabon, the Middle Congo, and Ubangi-Shari), the French Cameroons, and Togo. It also cites selected documents of the French Government, relating to its administration of these countries in the period 1946-58, and United Nations publications bearing directly on the trust territories of the French Cameroons and Togo.

Within each of these categories of publications, entries (a total of 405) are arranged alphabetically by author and title. An index provides a key to authors and subjects. Although official publications received by the Library served as the basic source for compiling the guide, they were supplemented by entries which other American libraries supplied to the National Union Catalog and by citations from published French and U.N. bibliographies. Locations in American libraries or the bibliographic source from which an item was taken are cited for each entry.

This publication is for sale by the U.S. Government Printing Office, Washington, D.C., 20402, at so cents a copy.

\section{Guide to Archival and Manuscript Sources relating to Africa in the United States}

THE Ford Foundation has awarded a grant to the African Studies Association for the production of a comprehensive descriptive guide to American diplomatic, commercial, educational, scientific, and other documentary sources relating to Africa over the past three and a half centuries. The National Historical Publications Commission, under the Chairmanship of the Archivist of the United States, has nominated an interdisciplinary group of Africanists chosen by the African Studies Association as an Advisory Committee for the project. The Guide will also serve as the United States national volume of the projected ' Guide to the Sources of African History' outside Africa, sponsored by the Unesco-affiliated International Council on Archives. It will provide comprehensive coverage of the African archives of 